\title{
Performance of young geese fed diets containing rye and enzyme preparations
}

\author{
$\therefore:$ \\ Elżbieta Pakulska', Halina Bielińska' \\ and Stefania Smulikowska ${ }^{2}$ \\ ${ }^{\prime}$ Research Institute of Animal Production, Experimental Farm Koluda Wielka \\ 88-160 Janikowo, Poland \\ ${ }^{2}$ The Kielanowski Institute of Animal Physiology and Nutrition, \\ Polish Academy of Sciences \\ 05.110 Jablonna, Poland
}

(Received 22 May 1995; accepted 22 August 1995)

\begin{abstract}
The nutritional value of a diet containing rye plus an enzyme preparation was evaluated on 480 White Italian goslings divided into 4 groups. All of the birds were fed a starter diet without rye for the first 3 weeks of life. From weeks 4 to 14 the goslings consumed the following diets: control group (C) without rye; experimental groups R, RE and HRE diets containing: 15\% (R and RE) or 20\% (HRE) rye between weeks 4 and 8 of life and $30 \%$ (R and RE) or $40 \%$ (HRE) rye between 9 and 14 weeks of life. The diets of groups RE and HRE were supplemented with $\mathrm{I} \mathrm{kg}$ /tonne of the enzyme preparations, Ryezyme (4-8 weeks) and Bio-Feed Plus (9-14 weeks). The diets were rationed, total consumption of all diets between 4 and 14 weeks of life was $20 \mathrm{~kg}$ per bird on average, additionally the geese consumed $33.5 \mathrm{~kg}$ of forage per bird.

At the age of 8 weeks the average live body weight (LBW) of goslings fed the rye diet unsupplemented with enzymes (group R) was lower than of controls, those fed rye diets supplemented with enzyme preparation (groups RE and HRE) higher $(P \leqslant 0.05)$. At the age of 14 weeks there were no significant differences in LBW between groups.
\end{abstract}

KEY WORDS: geese, performance, rye, enzyme preparations

\section{INTRODUCTION}

Rye has been the main cereal crop in Poland for many years and only during the last 10 years has its share decreased from about 40 to 25 percent of the total amount of cereals produced. In the future one should not expect further significant reduction of rye production since rye is well adapted to our climatic 
and soil conditions; it is much more tolerant to the low $\mathrm{pH}$ of sandy soil and more frost-resistant than winter barley and wheat (Wolski, 1994). Above $60 \%$ of the total rye crop is used as animal feed, however, its use as feed for poultry is limited.

Most of the existing research pertaining to the use of rye in poultry diets has concentrated on its adverse effects in feeding growing chicks. It has often been reported that incorporation of increasing proportions of rye into broiler chicken diets caused linear depression in growth rate and feed conversion ratio as well as watery, sticky excreta (Wagner et al. 1978, Friesen et al. 1991, Bedford and Classen, 1992).

From the few available reports it may be concluded that the effects of rye on the performance of young geese depend on the system of fattening used. It seems that in an extensive system it may be less adverse. Pakulska et al. (1995) reported that in such a system of fattening, at the age of 14 weeks geese fed forage and a diet containing $20 \%$ rye between 4 and 8 weeks of life and $40 \%$ in the consecutive 6 weeks weighed only $5 \%$ less than control geese. However, Wiliczkiewicz et al. (1992) observed that geese fed a diet containing $50 \%$ rye as the only feed from weeks 3 to 11 of life grew $16 \%$ slower, used $19 \%$ more feed per kilogram of body weight gain, had a lower dry matter content in the digesta and thicker intestinal walls than control birds fed a wheat and barley diet.

It is well documented (Pettersson and $\AA$ man, 1989; Bedford and Classen, 1992; Friesen et al. 1992; Boros and Marquardt, 1994) that digestibility of rye components in chicks and performance of young chicks fed a rye diet may improve markedly as the result of enzyme supplementation, however, no reports have been found on the effect of enzymes on performance of geese.

The aim of this study was to evaluate the effect of multienzyme preparations on the performance of young geese fed a rye-containing diet in an extensive system of feeding.

\section{MATERIAL AND METHODS}

The experiment was carried out in the Kołuda Wielka experimental farm of the Research Institute of Animal Production, between June and October 1994, on 480 White Italian goslings of the $\mathrm{WD}_{1}$ strain. From the first day of life the goslings were housed in a roofed concrete yard, littered with straw and divided into 12 separate compartments, each fitted with an open fowl-run and a water pond. Twenty male and 20 female one-day-old goslings with an average body weight of $110 \mathrm{~g}$, were randomly placed in each compartment. For the first 3 weeks all goslings were fed the same starter diet containing no rye (Table 1).

At the beginning of the 4th week, when the male goslings weighed an average of $1325 \mathrm{~g}$, females $1241 \mathrm{~g}$, four experimental groups were formed, each 


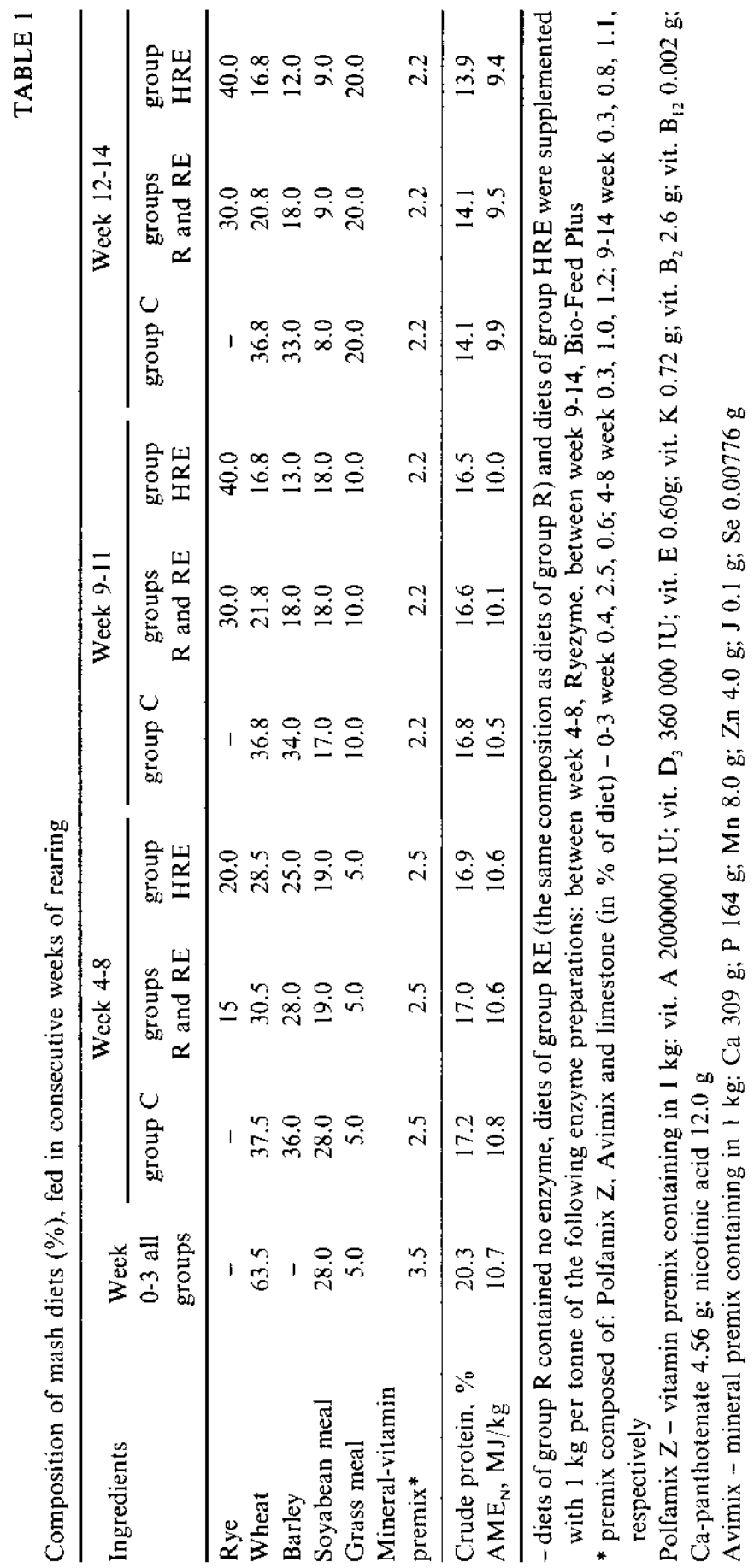


containing 3 compartments (120 goslings), each compartment containing 40 goslings was treated as a replicate.

The diets of the experimental groups differed only in the composition of their cereal portion; barley and wheat, which were the only cereals in control group diets, were replaced in part by rye in diets of groups R, RE and HRE. The composition of the diets fed during 3 consecutive periods of fattening changed: the protein level was reduced and the share of grass meal increased in all diets, the proportion of rye increased in diets fed to groups R, RE and HRE as the goslings grew older. The composition of the diets fed to group RE was the same as in group $\mathrm{R}$ except that feed enzyme was added to the former (Table 1). Diets fed to groups RE and HRE were supplemented with $1 \mathrm{~kg}$ per tonne of the following enzyme preparations: between weeks 4-8 Ryezyme (Alltech) containing xylanase and $\beta$-glucanase was added; during two consecutive periods Bio-Feed Plus (Novo-Nordisk) containing hemicellulase, $\beta$-glucanase, cellulase, cellobiase and xylanase was used. All diets were fed in mash form. Cereal grains and grass meal originated from the 1993 harvest.

All groups were fed according to the following schedule: during the first 4 weeks of life the goslings received feed ad libitum (from $0-3$ week starter, $4^{\text {th }}$ week experimental); from the 5 th week on the experimental diets were rationed, starting from $240 \mathrm{~g}$ ending with $180 \mathrm{~g} / \mathrm{bird} / \mathrm{day}$. Between weeks 4 and 14 of life the goslings were offered increased amounts of fresh forage containing grass (week 4), lucerne and clover (week 5-9) and green maize (week 10-14). The amount of forage offered per bird increased from about $100 \mathrm{~g} / \mathrm{bird} /$ day at week 4 to about $1 \mathrm{~kg} /$ bird/day by week 14 .

Between weeks 14 and 17 of life all birds were fattened, i.e. were offered ad libitum only whole grain: during week 15 barley, during week 16 barley and oats at a proportion of $1: 1$, during week 17 , oats. Water was always available ad libitum.

The intake of experimental diets and forage was registered weekly for each replicate. The intake of individual birds was not controlled, feed and forage were offered to each compartment according to the number of birds present. All birds were weighed individually at the beginning of weeks $3,8,11,14$ and 17 . Average body weight gain and feed conversion ratio were calculated for each replicate. At the age of 11 weeks the goslings were plucked by hand, white feathers, yellowish feathers and down were separated, pooled within the replicate, weighed and the average yield per bird in a replicate calculated.

Birds that had not reached marketing weight at the start of week 17 were classified as class B.

The data concerning live body weight of geese and yield of feathers and down were subjected to two-way analysis of variance. The means for groups were compared by the Duncan multiple range test. 


\section{RESULTS AND DISCUSSION}

There were some difficulties with supplying good quality forage because of a drought, so the total intake of forage per bird was lower (33.6 vs $50 \mathrm{~kg}$ ) and of experimental diets higher (20.2 vs $16.5 \mathrm{~kg})$ than in previous experiments (Pakulska et al., 1995). As the feed and forage were rationed, there were no differences in their intake between groups (Table 2).

At the age of 8 weeks the average LBW of geese fed the diet containing $15 \%$ rye unsupplemented with enzyme (group R) was lower than control (3686 vs $3786 \mathrm{~g} ; \mathrm{P} \leqslant 0.05$ ), a similar effect was found in previous experiments (Pakulska et al., 1995). However, geese that received the same diet supplemented with enzymes (group RE) were heavier (3811 g), geese of group HRE fed the diet containing $20 \%$ rye and enzyme were heaviest (3924 g on average). The differences in LBW between groups R, RE and HRE were statistically significant at $\mathrm{P} \leqslant 0.05$ (Table 3 ). It seems that the response of goslings to rye and enzyme supplementation is similar to that described for broiler chickens (Pettersson and Åman, 1989; Friesen et al., 1991; Bedford and Classen, 1992).

In the following period of 6 weeks the proportion of rye in the diets was increased to $30 \%$ in groups R and RE and to $40 \%$ in group HRE. The tendency for lower LBW in the group fed the rye diet unsupplemented with enzymes and higher LBW in groups fed enzyme supplemented rye diets persisted to the age of 14 weeks, however, the differences were not large and were not confirmed statistically. It may be presumed that older geese may adapt to the rye in a diet due to a change in gut bacterial population. An adaptive growth response of broiler chicks fed rye was reported by Wagner et al. (1978) and increased proliferation of gut microflora of the chick fed rye by Wagner and Thomas (1978).

The results of the study point to the positive effect of enzyme preparations added to the rye diets. In previous experiments, reported by Pakulska et al. (1995), geese fed diets containing 10 or $20 \%$ rye between weeks 4 and 8 of life and

TABLE 2 Average total intake of diets and forage between weeks 4 and 14 and grain in the final fattening period (in $\mathrm{kg} / \mathrm{bird}$ ) and feed conversion ratio ( $\mathrm{kg} / \mathrm{kg}$ body weight gain (BWG))

\begin{tabular}{lccccccc}
\hline \multirow{2}{*}{ Group } & \multicolumn{3}{c}{ Total intake, $\mathrm{kg}$} & & \multicolumn{3}{c}{$\mathrm{kg} / \mathrm{kg}$ BWG } \\
\cline { 2 - 3 } \cline { 7 - 8 } & Diets & Forage & Grain & & Diets & Forage & Grain \\
\hline $\mathrm{C}$ & 20.20 & 33.81 & 10.36 & & 4.22 & 7.07 & 8.36 \\
$\mathrm{R}$ & 20.19 & 33.65 & 10.80 & & 4.28 & 7.15 & 8.49 \\
$\mathrm{RE}$ & 20.19 & 33.58 & 10.60 & & 4.26 & 7.08 & 8.70 \\
HRE & 20.19 & 33.58 & 10.33 & & 4.24 & 7.06 & 8.30 \\
\hline
\end{tabular}


TABLE 3

Live body weight of geese, $\mathrm{g}$

\begin{tabular}{|c|c|c|c|c|c|c|}
\hline \multirow{2}{*}{ Week } & \multirow{2}{*}{ Sex } & \multicolumn{5}{|c|}{ Groups } \\
\hline & & $\mathrm{C}$ & $\mathbf{R}$ & RE & HRE & SEM \\
\hline \multirow[t]{3}{*}{3} & 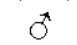 & 1344 & 1352 & 1377 & 1335 & \\
\hline & q & 1242 & 1256 & 1273 & 1194 & \\
\hline & $0 \%$ & $1293^{\text {sh }}$ & $1304^{\mathrm{ab}}$ & $1325^{4}$ & $1265^{b}$ & 13 \\
\hline \multirow[t]{3}{*}{8} & $\sigma^{x}$ & 3980 & 3840 & 4008 & 4170 & \\
\hline & $q$ & 3593 & 3532 & 3615 & 3679 & \\
\hline & $\delta 9$ & $3786^{b}$ & $3686^{\circ}$ & $3811^{\mathrm{b}}$ & $3924^{\mathrm{a}}$ & 31 \\
\hline \multirow[t]{3}{*}{11} & $\delta$ & 4898 & 4770 & 4871 & 4920 & \\
\hline & 우 & 4470 & 4300 & 4346 & 4317 & \\
\hline & $\delta q$ & $4684^{\mathrm{a}}$ & $4535^{a}$ & $4608^{a}$ & $4618^{a}$ & 40 \\
\hline \multirow[t]{3}{*}{14} & 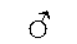 & 5152 & 5075 & 5124 & 5155 & \\
\hline & 우 & 4634 & 4558 & 4582 & 4576 & \\
\hline & $\widehat{O} 9$ & $4893^{a}$ & $4816^{a}$ & $4853^{a}$ & $4865^{\mathrm{a}}$ & 36 \\
\hline \multirow[t]{3}{*}{17} & $\sigma^{2}$ & 6440 & 6306 & 6395 & 6418 & \\
\hline & 웅 & 5833 & 5880 & 5772 & 5799 & \\
\hline & $\partial 9$ & $6136^{\mathrm{a}}$ & $6093^{4}$ & $6083^{a}$ & $6109^{a}$ & 50 \\
\hline
\end{tabular}

$a, b-$ means in the rows with the same superscripts were not statistically different at $P \leqslant 0.05$

20 or $40 \%$ rye without enzyme supplementation between weeks 8 and 14 , were at week 14 respectively 2 and $5 \%$ lighter than controls.

The main aim of the extensive system of fattening applied in the study is to obtain 14-week-old ganders weighing about $5200 \mathrm{~g}$ and geese about $4800 \mathrm{~g}$ (Nutrient Requirements of Poultry, 1993) able to consume large amounts of grain during the last 3 weeks of fattening. For the final economic result it is important that the number of birds classified at the end of the fattening period as grade $\mathrm{A}$, as well as the yield and quality of feathers and down obtained from the

TABLE 4

Average yield of feathers and down from plucking, $g /$ bird

\begin{tabular}{lrrrr}
\hline \multirow{2}{*}{ Item } & \multicolumn{5}{c}{ Groups } \\
\cline { 2 - 5 } & $\mathrm{C}$ & $\mathrm{R}$ & $\mathrm{RE}$ & HRE \\
\hline Feathers & & & & \\
- white & 35.6 & 35.2 & 48.7 & 38.2 \\
- yellowish & 33.9 & 34.7 & 26.9 & 33.6 \\
- total & 69.5 & 69.9 & 75.6 & 71.8 \\
Down & 5.2 & 3.8 & 5.0 & 3.7 \\
\hline
\end{tabular}

- no statistically significant differences between groups were found 
first plucking, be high. Both parameters were equal in all experimental groups, about $92 \%$ of the initial number of birds were finally classified as class $\mathrm{A}$, the total yield of feathers and down was on average even slightly higher in the RE and HRE groups than in the control group (Table 4). The birds fed rye-containing diets were as clean as controls, and no tendency towards a greater yield of yellowish feathers was observed in these groups. Mortality during experiment was only $2.3 \%$, which is within the normal range.

It seems that rye supplemented with an appropriate enzyme preparation may be a valuable component of feed mixtures used in an extensive system of fattening geese.

\section{ACKNOWLEDGEMENT}

Financial support from the Mellon Foundation and IESC is gratefully acknowledged.

\section{REFERENCES}

Bedford M., Classen H.L., 1992. Reduction of intestinal viscosity through manipulation of dietary rye and pentosanase concentration is effected through changes in the carbohydrate composition of the intestinal aqueous phase and results in improved growth rate and food conversion efficiency in broiler chicks. J. Nutr. 122, 560-569

Boros D., Marquardt R.R., 1994. Improvement of nutritional value of rye by enzyme application. Hod. Roślin Aklim. Nasien. 38, 95-110

Friesen O. D., Guenter W., Rotter B.A., Marquardt R. R., 1991. The effects of enzyme supplementation on the nutritive value of rye grain (Secale cereale) for the young broilcr chick. Poultry Sci. 70, 250]-2508

Friesen O. D., Guenter W., Marquardt R, R., Rotter B. A., 1992. The effect of enzyme supplementation on the apparent metabolizable energy and nutrient digestibilities of wheat, barley, oats and rye for the young broiler chick. Poultry Sci. 71, 1710-1721

Nutrient Requirements of Poultry. Nutritive value of feeds (In Polish). I $^{\text {nd }}$ ed. The Kielanowski Institute of Animal Physiology and Nutrition (Editor), Jabłonna, pp. 1-91

Pakulska E., Bieliniski K., Jamroz D., 1995. The use of ground rye for growing geese (in Polish). Rocz. Nauk Zoot. 22, (in press)

Pettersson D., Åman P., 1989. Enzyme supplementation of a poultry dict containing rye and wheat. Brit. J. Nutr. 62, 139-149

Wagner D. D.. Thomas O. P., 1978. Influence of diets containing rye or pectin on the intestinal flora of chicks. Poultry Sci. 57, 971-975

Wagner D. D., Thomas O. P., Graber G., 1978. An adaptive growth response of chicks fed rye. Poultry Sci. 57, 230-235

Wiliczkiewicz. A., Jamroz D., Skorupińska J., 1992. The effect of diets containing different levels of structural fibre on intestinal length, dry matter content of digesta, biochemical indices and electrolyte concentration in blood serum of geese. J. Anim. Fced Sci. 1, 117-126

Wolski T., 1994. Rye - the main cereal in Poland. Hod. Roślin, Aklim. Nasicn. 38, 5-10 


\section{STRESZCZENIE}

\section{Wplyw żyta i preparatów enzymatycznych na wyniki tuczu gęsi}

Doświadczenie przeprowadzono na 480 gąsiętach rasy Biała Włoska rodu WD, podzielonych na 4 grupy. Ptaki odchowywano do 3 tygodnia życia na mieszance starter nie zawierającej żyta, a od 4 do 14 tygodnia podawano następujące mieszanki: grupa kontrolna (C) otrzymywała mieszankę bez żyta, grupy R, RE i HRE mieszanki zawierające między 4 a 8 tygodniem 15 (R i RE) lub $20 \%$ (HRE) żyta, a między 9 a 14 tygodniem 20 (R i RE) lub 40\% (HRE) żyta. Do mieszanek RE i HRE dodawano następujące preparaty enzymatyczne: Ryezyme (między 4 a 8 tyg.) i Bio-Feed Plus (między 9 a 14 tyg.) w ilości $1 \mathrm{~kg} /$ tonę. W całym okresie odchowu gęsi $z$ wszystkich grup pobrały średnio okolo $20 \mathrm{~kg}$ micszanki i $33,5 \mathrm{~kg}$ zielonki na 1 ptaka.

Wprowadzenie żyta bez dodatku enzymu do mieszanki grupy $\mathrm{R}$ spowodowało obniżenie masy ciala gąsiąt w 8 tygodniu życia w stosunku do grupy kontrolnej, natomiast masa ciała gąsiąt $\mathrm{z}$ grup RE i HRE otrzymujących mieszankę zawierającą żyto i preparat enzymatyczny byla większa niż w grupie kontrolnej $(P \leqslant 0,05)$. W 14 tygodniu życia nie stwierdzono statystycznie istotnych różnic w masie ciała gęsi między grupami.

Wydaje się, że żyto z dodatkiem enzymów może zastẹpować inne zboża w ekstensywnym systemie odchowu gąsiąt. 